\title{
COLLABORATION AND VIRTUAL LEARNING IN NEW ZEALAND RURAL PRIMARY SCHOOLS: A REVIEW OF THE LITERATURE
}

\author{
Rachel WHALLEY \\ ORCID: 0000-0002-1990-788X \\ VLN Primary School \\ Matata, NEW ZEALAND \\ Michael K. BARBOUR \\ ORCID: 0000-0001-9037-3350 \\ College of Education and Health Sciences \\ Touro University California \\ Vallejo, USA
}

Received: 15/02/2019 Accepted: 10/09/2019

\begin{abstract}
In this literature review, the authors examined three key areas that were chosen as relevant to the challenges faced by small rural schools, and collaborative practice between schools working in virtual learning environments in New Zealand. The first area was rural education, where definitions of rurality and the demographics and characteristics of small rural New Zealand schools were described, and the challenges and innovations in rural school setting were explored. The second area was collaborative practice, where features of effective collaboration were discussed as is the professional practice and theory that underpins collaboration across school networks. Finally, the third area was virtual learning, which was defined and described, along with the benefits and challenges of learning in virtual environments, and the growth of networked learning communities in New Zealand was chronicled. A comprehensive scope of the current New Zealand education landscape was included to provide the context in which this review resides.
\end{abstract}

Keywords: Virtual learning, virtual school, cyber school, online learning, rural education, small schools.

\section{INTRODUCTION}

Virtual learning, which has been taking place in New Zealand for two decades, was pioneered in our rural schools (Barbour, 2011a; Roberts, 2010; Wenmoth, 1996). Stevens (1996) highlighted the changing role of small rural schools in relation to the development of school networks and virtual learning.

Small rural schools in New Zealand are in the forefront of changes in the application of information and communication technologies to teaching and learning. The emergence of rural school electronic networks is an important step towards the development of virtual classes in New Zealand, requiring new ways of organising teaching and learning. It is particularly appropriate to reconsider the pedagogy of the one- and two- teacher school in relation to the emerging virtual class. These small schools could have a new role in the information age and should, accordingly, be repositioned within the national educational system. (p. 93)

Written two decades ago, Ken Steven's words have challenged us to consider how virtual learning in small New Zealand rural schools have evolved over the last twenty years. This review aimed to explore how rural schools have led the way, and benefited from virtual learning; what challenges rural school principals have faced, how collaboration has taken place across schools in rural networks; and to what extent new ways of teaching and learning online have been enacted.

The Virtual Learning Network (VLN) Primary School network is an example of how small rural schools are collaborating online and backgrounds this literature review. The VLN Primary provides professional 
development for teachers, student learning support, technical support, and logistical coordination of online classes and programmes to schools around New Zealand (VLN Primary School, 2017). Learning is tailored to meet the needs of students, and to make the most of the strengths of the schools. For example, through a reciprocal arrangement, the schools provide teachers in a subject in which they have a high level of expertise. Where it isn't possible for schools to provide a teacher themselves, another teacher is contracted into the VLN Primary, collectively paid for by the schools. Students and teachers use a range of synchronous and asynchronous tools that enable them to communicate and learn online together. The VLN Primary School is a registered charitable trust governed by its participating schools and supported, in part, by the Ministry of Education (VLN Primary School, 2016). The Rural and Remote Schools Project was one of the projects supported by the VLN Primary School. This project, originally devised by principals and supported by the VLN Primary, had been running for five years with the same core group of principals. This project aimed to reduce the social isolation of students and teachers in rural and remote schools through regular online collaboration (Roberts, 2014).

A wide variety of sources were accessed in the process of writing this literature review. The University of Waikato library system and its many linked databases and journals was a key resource; the New Zealand Ministry of Education library was accessed and was a useful source of current educational articles and journals; educational websites such as TKI Educational Leaders was searched for relevant Principals' sabbatical reports and Education Counts and New Zealand Council for Educational Research (NZCER) were searched for relevant Ministry of Education reports and research.

Twitter provided connections to the American Education Research Association "Rural Education" special interest group, who were generous in sharing a Dropbox repository of international research in rural education. Professional networks developed over many years through participation in rural principals' conferences, elearning conferences, and collegial relationships with academics and teacher practitioners in virtual learning provided extensive knowledge of New Zealand research literature and educational reports. The authors' own participation and contributions to research in the field of virtual learning provided a source of literature that was relevant to virtual learning.

The main key word search terms initially used were: rural education, rural communities, rural principals, collaboration, virtual learning, online learning, blended learning, educational policy, schooling, professional learning. These search terms led in the direction of a range of literature that was aligned with the topic, which then allowed the researchers to filter through as being most relevant to the context being explored. The researchers regularly asked how applicable was this literature to the New Zealand K-12 setting, as well as how did what was being read agree or diverge from the general themes being found across the literature. As these lines of inquiry were followed, additional relevant search terms were emerging, such as: Maori learners, communities of practice, pedagogies, future focused, learning community, affordances of technology, access to technology, networks, and leadership. Through this process of scanning the literature widely, then telescoping in on areas that were most closely aligned with the research context, the researchers were able to critique, accept or discard the literature chosen for inclusion.

This review is organised into three key areas, chosen as relevant to the challenges faced by small rural schools, and collaborative practice between schools working in virtual learning environments. The three main areas are: rural education, where definitions of rurality and the demographics and characteristics of small rural New Zealand schools are described, and the challenges and innovations in rural school setting are explored; collaborative practice, where features of effective collaboration are discussed as is the professional practice and theory that underpins collaboration across school networks; and virtual learning, which is defined and described, along with the benefits and challenges of learning in virtual environments, and the growth of networked learning communities in New Zealand is chronicled. A comprehensive scope of the current New Zealand education landscape is included to provide the context in which this article sits.

\section{RURAL EDUCATION IN NEW ZEALAND}

Rural schools were considered by Stevens (1996) to be at the forefront of change in New Zealand education. This section explores rural education in New Zealand: definitions of rurality from the literature are synthesised as a basis for thinking about small rural schools; the characteristics of small rural schools and the important 
interdependent role they have within their communities are described; and challenges faced by principals of small rural primary schools and some innovative approaches implemented as a counter to these challenges are explored.

\section{Defining Rural}

There is much ambiguity in definitions of ruralness (Preston, Jakubiec, \& Kooymans, 2013; Stelmach, 2011). Perceptions of what is rural are multiple and changing, and based on socially constructed understandings which focus on geography, population, land use, and culture (Stelmach, 2011). For example, some have argued that definitions of rurality have traditionally been described as oppositional to urban areas, which results in polarisation and comparison between the two (Cloke, 2006; Stelmach, 2011). Instead of this divisive perspective, the concept of rurality "should not be seen in opposition to urban but part of a complex global economic and social network" (Donehower, Hogg, \& Schnell, 2007, p. xi). To illustrate this example, Statistics New Zealand (2004) defined rural areas on a continuum of greater or lesser urban influence. This has been determined by the number of people who live in the country but work in the town or city, and in addition the size of the closest urban centre. This type of definition is convenient for ease of collection of statistical data and monitoring of demographics, but it doesn't help provide a picture of what it means to be 'rural.'

Theoretical frameworks that define rurality in terms of space, place and society (Cloke, 2006; Halfacree, 2006) are more suited to this study as they support a descriptive definition that is more reflective of diverse perspectives of rurality. Cloke (2006) described characteristics of rural areas using this three-way framework: extensive land use such as agriculture (i.e., space), small settlements where there is a strong relationship to the land (i.e., place), and a way of life that has a cohesive identity and is intertwined with the landscape (i.e., society). These perspectives of thinking about rurality provide a basis on which to explore characteristics that are unique about rural schools.

\section{Characteristics of Small Rural Schools in New Zealand}

In order to explore the characteristics of small rural schools, it is first necessary to define these schools in their context within the New Zealand education setting. Just as there were conflicting views on what constitutes ruralness, Starr \& White (2008) asserted there were also differing views on what constitutes a small school. The Ministry of Education (2013), in a survey of school ICT infrastructure, profiled small schools as having a student roll of 199 or less, and very small schools as having a roll of less than 100. In these small schools most principals are also teaching principals or sole charge teaching principals. New Zealand schools are graded U1 to U16 according to the number of students they have. The $\mathrm{U}$ grading of a school determines principals' salaries and the number of teachers a school can employ, as well as other resources allocated to the school. A principal will be the only teacher at a school, or "sole charge," until the roll exceeds 25 pupils, after which he or she will continue to have a teaching role that reduces depending on the size of the roll and staffing allocation. Many small rural schools are also considered by the Ministry of Education to be isolated, and receive targeted funding to assist them with additional resourcing costs. Of the 478 schools receiving targeted isolation funding in 2015, 64\% were small primary schools with a roll of less than 100; and for 89 of these schools, isolation funding made up 10\% of their operational grant (Ministry of Education, 2016a).

Table 1. Small school demographics 2017 (Data extracted from New Zealand Schools Directory (Ministry of Education, 2017a).

\begin{tabular}{cccc}
\hline School Grade & Maximum Roll & Number of Schools & Percentage of Schools \\
\hline Sole Charge & 25 & 143 & $6 \%$ \\
U1 & 50 & 223 & $9 \%$ \\
U2 & 100 & 330 & $13 \%$ \\
U3 & 150 & 278 & $11 \%$ \\
\hline Total Schools & & 2530 & $39 \%$ \\
\hline
\end{tabular}

U1 grading includes sole charge principals but has been separated out in this comparison. 
This literature review focuses on New Zealand Sole Charge to U3 primary schools situated outside of town and city boundaries. This type of school best suit the demographic referred to in the introduction, as the small rural school that "could have a new role in the information age and should, accordingly, be repositioned within the national educational system" (Stevens, 2016 p. 93). With this clear definition of small rural schools in mind, the characteristics of these schools can be discussed in context.

In conceptualising rural schools in the wider sense, Green (2015) proposed a threefold framework, similar to that presented in the previous section to describe definitions of rurality, of space, place and scale. This framework gave impetus to the importance of community involvement, rural identity and place based education as well as social, economic and environmental sustainability. The New Zealand rural school is an integral part of its community (Kearns, Lewis, McCreanor, \& Witten, 2009; Wright, 2007). Therefore it is important not to consider schools in isolation. Green (2015) stated that:

thinking beyond the school is crucial, but that does not mean that schooling is now somehow irrelevant, or marginalised. Rather, it is to say that schools are embedded in communities, and potentially integrated with them, as multi-scalar sites of communication and learning, being and becoming. (p. 46)

Corbett (2007) explored identity and social capital of students in rural school settings. He identified some young people as having "mobility capital," which was the confidence and skills to negotiate various spaces outside of the school and community setting. While some young people possess more "localised capital," which is a strong grounding in the local community, with future opportunities that are locally based. This difference in social capital can create tension within rural communities about the purpose and value of education and the relevance of curriculum. Some parts of the community are more outward looking and seek an education that will prepare their children for going out in the world for higher education or wider employment prospects, while others are more inward looking, seeking an education that will prepare their children to remain and take up their place working within their own community.

Barley and Beesley (2007), in their study of successful rural schools, found that schools and their communities were interdependent, with the school as the hub of the community and the community providing support to the school. Families had a high personal investment in the school, as many identified with the school as former students. Close relationships were developed between the principal and community, and high expectations were placed on students to achieve well. Children in small rural schools with supportive communities experienced close relationships with others through learning to get along with a small number of children, and through a safe school environment where everyone knew each other. Children learned valuable life skills of tolerance, negotiation and commitment, and, in the process, forged social connectedness and strengthened communities (Wright, 2007). Rural schools are a popular choice for parents because of their small class sizes, extensive amenities, family atmosphere, and high expectations for good behaviour, participation and learning achievement for their students (Earl Rinehart, 2017).

Wright (2003) discussed the importance of rural schools developing a local curriculum in partnership with their communities, so that children might have knowledge of their own area, history and environment; community values were preserved; and students potentially had better educational outcomes. Place based education, or local curriculum, has the potential to revitalise rural schooling (Bartholomaeus, 2013; Green, 2015). With this approach students can be given the opportunity to pursue questions relevant to them, while they can develop stronger community ties and an understanding of their local place and of themselves (Bartholomaeus, 2013).

For many students in rural and remote areas, continuing their schooling to high school means they will have to leave their communities to attend boarding school. For some the alternative to leaving is to be homeschooled or enrol in Te Aho o Te Kura Pounamu (i.e., The Correspondence School). This time of transition has been highlighted by rural school principals as an important process for rural children, and one that needs to be carefully prepared for. Students who are well supported by their family and teachers, and are resilient, confident and independent are more likely to make successful transitions to secondary school (Baills \& Rossi, 2001; Johnson, 2016; Vincent, 2015). Rural principals have high expectations placed on them, not only as the leader of the school, but also as a community leader (Earl Rinehart, 2017); which creates specific challenges that principals face in small rural schools. 


\section{Challenges for Rural Principals}

Stelmach (2011) raised a range of issues that impact on rural communities and their schools. Out-migration (i.e., where families leave the community), gender inequality, poverty, geographical and psychological remoteness all affect schools, resulting in declining enrolment, and difficulty attracting and retaining staffing. There may be differences of opinion between the community and the principal on the value and purpose of education. Globalisation influences rural communities in both positive and negative ways, either providing regeneration of some communities, or increasing the polarisation between city and country and creating further inequality. Globalisation also influences educational policy, which has a roll down effect on schools and the principals who lead them (Starr \& White, 2008).

Starr and White (2008), in their research with principals in Australia, found principals of small rural school spend most of their time teaching multi-level classes, with little support for school administration. The tasks required to manage a small school are the same as for larger schools, with no opportunities to delegate to others. "While principals raised many types of challenges, the most commonly raised themes concerned: workload proliferation, educational equity issues... escalating role multiplicity, and school survival" (p. 3). Relationships and communication with a wide range of people are described by Earl Rinehart (2017) as being a significant part of a rural principal's role. This was considered significant, not only for the energy in supporting so many different relationships, but in the workload and complexity it contributes to a principal's day through managing so many communications. Preston et al. (2013) noted that if principals don't share common social, cultural or ethnic connections with their community, then they could experience levels of mistrust from the community.

Rural schools are often under resourced and have additional pressures unique to their position (McLean, Dixon, \& Verenikina, 2014), which can result in stress, heavy workload, and strain on family and relationships for principals (Windsor, 2010). Windsor surveyed and interviewed New Zealand rural school principals during her sabbatical, and found that multi-level teaching and finding a balance between being a principal and being a teacher was the most difficult part of a rural principal's job. Managing relationships in a small community was a source of tension for many principals, especially regarding differences of opinion on how the school is being run. Specialist support and the lack of governance experience was another challenge faced by principals. Providing for children with special needs was difficult, with limited resources and access to specialist services and personnel (Stansfield, 2015). These challenges may be contributing factors to the turnover rate of principals that Wylie (2017a) found is higher in small rural schools than other types of schools.

Transience of the community and fluctuating rolls have been identified as a growing problem in small rural schools. Hayward (2008) described this problem in this manner: "the major worry that affects small school rural principals in NZ are the enrolment numbers in our schools around March and July" (p. 3). Reduced numbers will see a reduction in funding and the potential loss of teaching staff to the school. These fluctuations in student numbers can have a significant impact on the future of a small school, making them vulnerable to closure. In the 1990s, 95 small New Zealand rural schools were closed, and another 75 schools in the early 2000s, under a process of network reviews. This process, called "Education Development Initiatives," was a response by the New Zealand government to changing rural demographics, falling school rolls and perceived underperformance in schools. These school closures had a profoundly devastating effect on many rural New Zealand communities (Kearns et al., 2009).

Access to professional learning is considered a significant concern by principals. Access can be limited by the cost of attending professional learning events due to distances to travel and finding relievers (Stansfield, 2015; Wylie, 2017b). Lack of time is often an issue, not just to attend professional learning, but also to reflect on, process and implement new ideas gained from professional learning (Windsor, 2010; Preston et al., 2013). Being a principal in a small rural school can be professionally and socially isolating, with limited opportunities to connect with colleagues for support and sharing of ideas (Earl Rinehart, 2017).

In small rural schools, principals are concerned that they have few opportunities to share and compare ideas and practices with other schools, and thus cannot judge the extent of their progress. As one rural principal commented, "it can be scary because how do we know if we are doing the right things?" (Cowie \& Hipkins, 2009, p. 20). This was supported by Stockton (2009), in his study of curriculum implementation in small 
rural schools, where he described the difficulty in undertaking professional curriculum inquiry because of the limited range of ideas and experiences to draw upon within small schools.

Although rural principals and their communities face many challenges, the literature indicates there are a variety of positive experiences in small rural schools. These schools know their children and families very well, and have committed teachers and strong community support (Barley \& Beesley, 2007; Kearns et al., 2009; Stockton, 2009). In addition, by being an integral part of a small community in some of the most unique settings in New Zealand, there are many rich opportunities generated for place based pedagogy (Windsor, 2010; Wright, 2007). Stansfield (2015) describes small island schools as having an "abiding sense of place" (p. 5.), and a strong affinity with the environment. The context of small rural schools can provide principals with many challenges but also positive experiences. Innovative approaches to are often found in small rural schools.

\section{Innovative Approaches in Rural Schools}

Rural principals have responded to challenges by seeking innovative approaches to deliver better outcomes for their learners (Stansfield, 2015; Starr \& White, 2008). For example, one innovative approach by the Halfmoon Bay School community, when faced with loss of staffing due to a fluctuating roll, was to advertise on Trade Me (i.e., New Zealand's largest Internet auction website) for families to come to live on the island with free accommodation and job offers (Mcleod, 2015). Along with boosting the school roll, which enabled them to maintain their second teaching position, they gained national attention and raised the issue of inequity in staffing formulae for rural schools.

Responding to the challenges of rural schools also necessitates an approach where schools partner with whanau (a Maori term used to describe extended families or related families), community organisations and the government to secure better resourcing of both finances and expertise (O'Leary, 2015). However, this approach can bring a different set of challenges such as a loss of autonomy and a change in values (Stelmach, 2011). Strategies such as working across schools and extensive use of technologies can help principals to counter many of the challenges of professional isolation (Starr \& White, 2008; Windsor, 2010; Wright, 2012). It is this collaboration across schools, and the use of technologies in the form of virtual learning, which is explored in the subsequent sections.

\section{COLLABORATIVE PRACTICE}

Collaboration between schools is one of the innovative ways that small rural schools lead change. This section focuses on the form and function of professional practice that supports collaboration that can lead to improved and equitable learning outcomes for students. Features of effective collaboration are outlined and linked with theories of Communities of Practice and Connectivism that underpin collaboration across school networks.

\section{Collaboration - Form and Function}

Collaboration is one of the leadership practices that can contribute to collective efficacy, which is teachers' collective belief that together they can make a difference to student learning (Donohoo, 2017). Student achievement can be improved when teachers collaborate to overcome challenges (Fullan, 2015; Ronfeldt, Farmer, McQueen, \& Grissom, 2015). Furthermore, collaboration between schools has the potential to improve equity for students, by increasing the capacity of schools to respond to learner diversity (Ainscow, 2016; Chapman, Chestnutt, Friel, Hall, \& Lowden, 2016).

Collaboration requires a shared vision and purpose; and clear structures and processes, including time and resources (Donohoo, 2017; Rincón-Gallardo \& Fullan, 2016; Taskforce on Regulations Affecting School Performance, 2014). Effective collaboration, through inquiry and group problem solving, avoids the problem of "group-think," where individuals repeat and reinforce similar view; and seeks to gain deeper understanding rather than perpetuating the status quo (Donohoo, 2017; Rincón-Gallardo \& Fullan, 2016). 
Collaboration in schools takes place on a continuum from informal meetings to highly structured activities (Taskforce on Regulations Affecting School Performance, 2014). Starr and White (2008) identified several levels of practice across schools: networking, which involved the simple sharing of information; coordination, which was to work together for a common purpose, for example organising a cluster schools sports day; cooperation, which extended on the previous concepts but involved the sharing of resources between schools and a higher level of trust; and collaboration, which involved all of these concepts but required everyone to be working towards building the capacity of the group of schools as a whole, resulting in local trade-offs to achieve a common purpose. Taylor-Patel (2014) stated that "effective collaboration in education is about leaders being committed to working for all students in all schools, as they do their own" (p. 52). Effective collaboration in education takes place at a deeper level on the continuum of how schools work together to collectively improve outcomes for their learners.

Collaboration can be differentiated between system based, formal, top-down collaboration and a culture of collaboration that is informal and grassroots driven. Effective school networks need both approaches (Daly, 2010; Feys \& Davos, 2016; Rincón-Gallardo \& Fullan, 2016; Taylor-Patel, 2014). Grassroots collaboration can be more genuine and effective than mandated collaboration. Yet system based support is needed to provide the resources and structure that enable schools to collaborate (Taylor-Patel, 2014). Collaboration that is imposed and contrived to achieve system goals was found by Hargreaves and O'Connor (2017) to be harmful, reducing teachers' motivation to initiate further collaboration. The Taskforce on Regulations Affecting School Performance (2014) stated, "consultation feedback and research agree that forced or mandated clustering is not sustainable. Collaboration should be based on mutual need and benefit" (p. 26). Drivers for collaboration whether grassroots or mandated can seem to be contradictory but when combined can support effective collaborations.

Duffy and Gallagher (2017), when discussing a Northern Irish collaborative initiative "Shared Education," voiced concerns that the project which had been strongly grassroots driven in the past, might lose its edge for innovation and creativity because its funding and management had been taken over by the government. Daly (2010) contended that formal structures are important for providing policy and structures that support collaboration, challenge teacher norms, and give access to expertise. However, it was important to first understand the informal networks and relationships that existed. Rincón-Gallardo and Fullan (2016) listed the features of effective network as:

- focussing on ambitious student learning outcomes linked to effective pedagogy;

- developing strong relationships of trust and internal accountability;

- continuously improving practice and systems through cycles of collaborative inquiry;

- using deliberate leadership and skilled facilitation within flat power structures;

- frequently interacting and learning inwards;

- connecting outwards to learn from others;

- forming new partnership among students, teachers, families, and communities;

- and securing adequate resources to sustain the work. (p. 10)

Effective collaborations across school networks have the capacity to deepen learning, grow professional capital and be a positive driver for system improvement.

\section{Collaboration in Schools and Theories of Networked Learning}

The context of this literature review is on collaborative practice across groups of schools, and not within individual schools. Fullan (2005) espoused the benefits of professional learning communities to foster collaboration and develop the collective capacity of staff to improve student achievement, and he contended that this should be writ large to extend across school districts and nationally to build system wide capacity. Being part of a professional network, cluster or learning community is important for rural principals to not only provide a support network but to build professional knowledge (McLean et al., 2014). New Zealand Principal's Federation President, Iain Taylor in Education Review (2016), acknowledged collaboration as a long-standing practice of principals and, although for rural principals there were some barriers to 
participation, an important part of their professional learning and support. Cowie and Hipkins (2009) supported this when they said, "effective leaders are strongly networked, with connections to various groups that provide professional and personal support" (p. 21). Being connected and networked to other professionals is important, but it is just the starting point towards collaborative practice across schools.

Social connections, shared purpose, strong relationships and capacity building in learning communities are at the heart of successful collaborative practice. McLean et al. (2014) profiled "communities of practice" as a theoretical framework for developing professional communities and connectedness for teachers in isolated rural communities. Communities of practice is a social theory of learning whereby groups of people collectively create knowledge and meaning through a common purpose and shared practice in both formal and informal settings (Wenger, 2008). Owen (2011) stated that teachers participating in communities of practice can share conversations and practice about learning and teaching and have the support of a professional network.

Collaborative professional networks can build their capacity through developing the social and professional capital of their members. The concept of social capital can be described as the connections between individuals and groups built on relationships, trust, shared norms and reciprocity which provides benefit to the network (Ainscow, 2016; Tokas, 2016). Hargreaves and O'Connor (2017) expanded on the concept of social capital, including it within a wider concept of professional capital:

\section{professional capital is made up of individual human capital, the decisional capital of capacity to make judgments that develops over time, and the social capital of trust, interaction, shared purposes, and collaborative relationships among an occupational community. Social capital is at the heart of professional community - the way that teachers work together as an occupational and social group. (p. 74)}

Technology has enabled us to collaborate and learn more easily across networks of schools. Connectivism was proposed by Siemens (2005) as "a learning theory for the digital age" (p. 1). However, while not all would agree it is a learning theory per se, it does provide a useful framework for learning in digital networked communities (Duke, Harper, \& Johnston, 2011; Harasim, 2014; Kop \& Hill, 2008; Starkey, 2012).

Within a connectivist framework knowledge is distributed across networks, and learning is a process of connecting through networks. Nodes on the network can be individuals, communities, organisations or sources of information (Siemens, 2005). Connectivism can be evidenced in New Zealand by the many schools that have self-organised as networked communities of learners. Networked schools collaborate with other schools, often through virtual learning (Ministry of Education, 2011a).

\section{VIRTUAL LEARNING}

Virtual learning has been accepted practice in small rural New Zealand schools for many years. This section defines online, blended, distance and virtual learning, detailing virtual learning operations and the growth of networked communities of schools in the New Zealand educational setting. The benefits and challenges of virtual learning are discussed, and learning support for students in virtual environments is explained.

\section{Defining Virtual Learning in New Zealand}

Virtual or online learning can mean different things to different people depending on their individual experiences and understandings, and these terms have often been used interchangeably (Barbour, 2014; Whalley, 2016). Research literature abounds with overlapping, inconsistent and confusing terminology, which complicates analysis of this field of education (Guri-Rosenblit, 2005). Furthermore, the area of online and blended learning is complex, involving many different features and models of practice (Cavanaugh, Ferdig, \& Freidhoff, 2017). Commonly used terms in this field of study are elearning, virtual, online, blended, flexible, open and distance learning.

Distance learning is characterised by the separation of place and or time between teacher and learners and learning resources (Lai, Pratt, \& Grant, 2003). Distance learning has evolved over a range of stages that are described as generational, beginning with print based media and correspondence, moving through to television and radio broadcast, and continuing to different media, technology, pedagogies and systems of the times (Anderson \& Dron, 2011; Bates, 2005; Moore \& Kearsley, 2012). 
Blended learning has arisen through the convergence of technology and pedagogy of online and distance learning and the developing use of technology within face to face schooling settings (Lai, Pratt, \& Grant, 2003; Ministry of Education, 2011a). Blended learning is characterised by students combining part of their learning online and part in the bricks and mortar school setting, giving them more choice and flexibility in their learning (Barbour, 2015; Staker \& Horn, 2012).

Some critics see online learning as students being taught by technology, with no social interactions with teachers or their peers (East, 2016). Those with practical experience in the field of online learning hold a different view. For example, Cavanaugh, Ferdig, and Freidhoff (2017) asserted that quality online learning involves "high quality and interactive content, teachers with strong and specific pedagogical skills, training for parents and students, and strong mentoring and scaffolding opportunities" (p. 53). Further, Parkes, Gregory, Fletcher, Adlington, and Gromik (2015) noted that strategies for successful online learning include providing learning in multiple formats, lots of opportunities to communicate, developing communities of practice and networks, creating learning environments that encourage social presence, and access to support. Social presence being defined by Palloff and Pratt (2008) as "the degree to which a person is perceived as 'real' in communication that is conducted via the use of some form of media" (p. 30). Social presence, along with teaching presence (i.e., the design and facilitation of learning) and cognitive presence (i.e., the ability to make meaning) form the 'Community of Inquiry' framework developed by Garrison, Anderson, and Archer (2010), and is considered important in engaging young people in online learning (Borup, West, Graham, \& Davies, 2014).

Virtual learning can be broadly defined as learning that is facilitated by a range of online technologies to enable communication and collaboration, where students and teachers are in different physical locations (Bolstad \& Lin, 2009). In addition, virtual learning is an important activity in networks of schools and could, over time, change the nature of schooling (Ministry of Education, 2011a). Barbour, Miron, and Huerta (2017) qualified their use of the terminology 'virtual school' to describe supplementary online learning taking place in schools, in comparison with cyber schooling, where children learn fully online in cyber charter schools, and with the term online learning, which is used in more general terms. To be able to fully understand virtual learning in the New Zealand schooling sector, it is necessary to view its evolution over the last three decades.

\section{A Background to Virtual Learning in New Zealand}

Virtual learning has been taking place in New Zealand schools for more than two decades. Since the early 1990s schools have collaborated to share teachers and resources and provide online classes to each other's students through the internet (Ali, 2017; Powell \& Barbour, 2011; Roberts, 2010; Starkey \& Stevens, 2007; Stevens, 2011). Clusters of schools began to collaborate to teach online classes using audiographics in 1994. Canterbury area schools initiated Casatech (Langley, 2003; Stevens \& Moffatt, 2003; Wenmoth,1996); and later TosiTech (i.e., Top of the South Island Technology) was formed (Barbour \& Wenmoth, 2013; Roberts 2009). Audiographics required two phone lines, one to provide the audio connection and another to send still images to a computer screen (Ali, 2017; Stevens, 1995). More schools began to work in similar ways, such as Ngata Memorial College, who, in partnership with Te Puni Kokiri, made these recommendations to the Ministry of Education:

- that they recognise their pioneering role in telelearning education and support the expansion to other New Zealand schools;

- that links be expanded to Colleges of Education; that they recognise the Maori cultural context and consult with the broader Maori community; and

- and that they should no longer be considered a small school but be funded as a virtual school (Stevens, 1998).

Stevens differentiated distance education as belonging to an industrial age model and telelearning to the information age. He described a changing educational environment becoming evident in schools, where schools were inter-connected through Information Communication Technonolgy (CT) networks, and using technologies to provide new and better ways of learning. 
The Kaupapa Ara Whakawhiti Matauranga (KAWM) network initiative, begun in 2000, enabled several school clusters, consisting of Wharekura (i.e., full immersion Maori schools), East coast area schools \& Maori boarding schools, to use video conferencing to provide online classes and professional development for teachers (Barbour \& Wenmoth, 2013; Roberts, 2009; Waiti, 2005). Evaluation of the KAWM initiative made recommendations that there needed to be: more development in the knowledge and skills appropriate for a learner centred curriculum and teacher pedagogies in the digital age; robust and effective technology infrastructure; and adequate and ongoing funding to support schools to coordinate elearning (Waiti, 2005).

Following on from the KAWM initiative, many more regional clusters formed in quick succession over the decade and became collectively known as the Virtual Learning Network (VLN), until by 2010 over half of New Zealand's area schools and secondary schools had some students learning online (Powell \& Barbour, 2011). These school networks were developed to meet the needs of small rural schools to enable them to extend the curriculum for their students (Roberts, 2010; Stevens \& Moffatt, 2003). Schools were at risk from declining rolls and pressure to retain staff (Ali, 2017). There was dissatisfaction with The Correspondence School, which had traditionally provided courses to rural senior students (Ali, 2017; Langley, 2003; Roberts, 2009). Additionally, school leaders were beginning to realise the potential of emerging technologies that would enable schools to collaborate online (Langley, 2003). With telelearning, schools should no longer be considered as small schools when they are open and networked with other schools. Stevens (2010) elaborates on this point when he states, "an increasing number of schools in rural [New Zealand] have increased in size in terms of the curriculum they provide both on-site and online" (p. 171). This move from closed to open contributed to the sustainability of education in small rural communities (Stevens, 1998; Stevens \& Stewart, 2005).

There was little documented about virtual learning at the primary school level until the formal development of the VLN Primary School in 2009. Online learning in New Zealand is mainly provided by the VLN Primary (Williamson-Leadley \& Pratt, 2017). The VLN Primary aims to extend learning opportunities for students by enabling online collaborations between schools (Ministry of Education, 2017b; Tolosa, East, Barbour, \& Owen, 2017). In 2004 the then principal of Pitt Island School in the Chatham Islands, realising how the secondary school sector was making use of virtual learning, looked to collaborate online with other schools in New Zealand (Whalley, 2016). In 2008 this principal led the collaboration of three schools to share online language classes, and a case study was developed that resulted in the Ministry of Education supporting the fledgling VLN Primary School (Gibson, 2009). Although the VLN Primary School was initiated to support the provision of Years 7 and 8 languages (Owen, 2013), it was soon realised that there was an opportunity to widen the range of curriculum choices, to provide a variety of learning experiences in addition to formal classes, and to grow the professional capacity of teachers to better meet the needs of learners and teachers (Barbour, 2011b; Roberts, 2014). There is a small percentage of primary age students enrolling in virtual classes compared with secondary students, but in recent years there has been significant growth (Barbour, 2014; 2015). By 2017 the VLN Primary School had grown to 870 students, a 400\% increase in growth over a five-year period (Whalley, 2017).

The development of new technologies and the improvement of broadband services to schools were significant in the growth of virtual learning in New Zealand. Project Probe, initiated in 2002, enabled schools to move from audiographics to video conferencing (Roberts, 2009). More recently, considerable investment by the government in schools' infrastructure, fibre and rural broadband rollouts, and the development of a dedicated managed network for schools providing free, fast internet have enabled all schools to have the technology needed to access virtual learning opportunities (Roberts, 2014). However, statistics from the World Internet Project indicate there is still a growing digital divide for communities in rural areas (Crothers, Smith, Urale, \& Bell, 2015).

\section{Benefits and Challenges of Virtual Learning}

The Learning Communities Online Handbook (Ministry of Education, 2011a) was written by New Zealand teachers who were active practitioners in the field of virtual learning. They described wide ranging benefits such as access to greater curriculum choices, access to experts, engagement in collaborative projects and learning that is high interest and relevant to students' interests, extension for gifted and talented students, 
sharing of resources, provision of professional learning, retention of specialist staff, and retention of students. Thomson (2011) described the benefits of online learning as allowing flexibility and freedom from the traditional expectations of school, and a personalised learning experience for students which caters for different skill levels and interests, promotes a student-centred pedagogy, provides social benefits through interacting with other students, and encourages students to take responsibility for their own learning.

In addition to the benefits described above, virtual learning in schools has been an impetus for innovation and change in promoting a learner centred pedagogy, collaborative teaching practice, changes to schools' organisation such as timetabling and shared resourcing, changes to teachers' roles, and a teaching and learning environment that is more aligned to a twenty-first century networked school (Barbour, 2011b; Barbour, Davis \& Wenmoth, 2013; Langley, 2003). Virtual learning is credited with creating educationally powerful connections where students can connect to others, in New Zealand or globally, in authentic and relevant learning contexts. In describing the work of the VLN-Community, the Ministry of Education (2011b) said, "they have been able to provide their students with opportunities to develop aspects of the key competencies and exercise digital citizenship, and the students are demonstrating improved academic engagement and motivation across the curriculum learning areas" (p. 2). Although there are many benefits for students who learn virtually, it is important to consider some of the challenges and how learners can be supported in the virtual environment.

One New Zealand primary school found their participation in virtual learning related to themes of lifelong learning in a connected world, personalisation of learning for students, and digital citizenship (Ministry of Education, 2017b). Two key areas the school felt needed more attention were making the connection between students' virtual learning and their classroom learning, and providing better support for online learners. Tolosa et al. (2017) found that students learning languages online with the VLN Primary were able to access languages that otherwise wouldn't have been available to them, were developing digital literacies and intercultural awareness, and had a very positive attitude to learning languages reinforced through the online environment. However, there were barriers experienced by some students in terms of the technological infrastructure and the time and independent study skills needed outside of online classes to progress their language learning.

Parkes et al. (2015) stated that high attrition rates, lack of support, lack of timely effective feedback, reliability of and access to technology, and digital divide are all issues for online learners and are exacerbated for disadvantaged students. However, Whalley (2016) in his study exploring the factors that affect student success in virtual learning environments, found that school-based support for learners was critical. To effectively support students learning in virtual environments schools need to:

- ensure that they had policy and procedure in place;

- have systems for keeping track of students learning;

- provide the infrastructure and resources for learning;

- promote a tuakana/teina (i.e., Maori concept of older or more experienced children teaching younger children) culture of learning in the school where students support each other;

- have effective communication across the whole school community including whanau; and

- support students to reflect on their own learning.

With deliberate strategies of student support in place, learners can be more resilient to the challenges of learning in virtual environments.

\section{SCOPING THE CHANGING SCHOOLING POLICYSCAPE}

In considering how virtual learning in small New Zealand rural schools has evolved over the last twenty years since the emergence of rural school electronic networks, it is necessary to understand the effect of policy in the wider educational context. This section gives an overview of schooling policy and initiatives in New Zealand over the last two decades. 


\section{Tomorrow's Schools}

Set against a backdrop of wider economic and political reform of the 1980s, the Education Act of 1989 legislated for a raft of changes that were known as "Tomorrow's Schools" (Taskforce on Regulations Affecting School Performance, 2014). Schools became self-managing standalone entities, each with their own board of trustees, charter, policies and operational funding. They worked independently of the new Ministry of Education, whose role it was to create policy and provide funding. Other government agencies, such as the Education Review Office, were created to provide accountability and support for schools. These changes were brought about with the goal of making schools more efficient, accountable to their communities (Earl Rinehart, 2017) and government, more flexible and responsive, and less bureaucratic. There was an assumption that these changes would lead to better teaching and learning through providing more choice for parents and competition between schools (Earl Rinehart, 2017; Langley, 2009; Wylie, 2012).

Tomorrow's Schools presented many challenges to schools. Bureaucracy was not reduced as intended, but shifted to the individual school environment, where more compliance issues were created through interactions with and accountability to several new government agencies. Principals' workloads grew tremendously through the introduction of Tomorrow's Schools (Earl Rinehart, 2017; Wylie, 2013); and with the introduction of the new curriculum and assessment regimes in the late 1990s, teachers' workloads also became large and unmanageable (Wylie, 2013). Competition between schools inhibited collaboration and created a stratified education system of winner and loser schools (Langley, 2009; Wylie, 2012), with low decile schools, rural schools and schools with a high number of Maori students finding it difficult to attract and retain principals (Wylie, 2012). With schools working in competition and in isolation from each other, it is difficult to create systems capacity that drives improvement in teaching and learning. For this reason, Wylie $(2012$; 2013) recommended changing the Tomorrow's Schools model to a system of networked schools, such as school districts, that would enable more collaboration, shared responsibility and equity across the education system. Although Tomorrow's Schools is now nearly 30 years old, New Zealand schools still work largely within this model. However, recent government reforms see schools poised for a step change with the advent of "communities of learning" or Kahui Ako. The current government has initiated a system wide review and consultation around the future of education in New Zealand including changes to the Tomorrow's Schools framework (Government of New Zealand, 2018).

The Tomorrow's Schools Review Taskforce Report (Ministry of Education, 2018) outlined several key areas for improvement in the New Zealand schooling system and made recommendations on: changing the governance structure of schools to reorient the role of Boards of Trustees and create Education Hubs to govern networks of schools; developing a national school network strategy to improve schooling provision; creating more coherent structures and resourcing that will reduce competition between schools, provide more disability and learning support and provide equitable access to resourcing for schools especially for disadvantaged schools, small schools and primary schools. The report recognises that small rural and remote schools have difficulty in providing a broad curriculum and that "Te Kura has the potential to have a greater strategic role in the provision of flexible schooling, curriculum and timetabling for all students, not just those in alternative education" (p. 63). Although the report focuses only on Te Kura as having this strategic capability, the VLN can also be considered as a valuable system resource as "the VLN and Te Kura both have great potential to support and facilitate innovation in online curriculum content, learning, pedagogy and assessment" (p. 64). The Tomorrow's Schools Taskforce Report is in the process of consultation until April 2019 and when progressed will initiate the biggest schooling system changes in New Zealand since the 1990s.

\section{DEVELOPMENT OF COMMUNITIES OF LEARNING/KAHUI AKO}

Government initiatives in recent years have been moving the New Zealand education system towards engaging in more connected, collaborative, school networks. 'Networked Learning Communities,' supported by the Ministry of Education between 2008 and 2010, were set up to assist schools to engage with and implement the New Zealand Curriculum. These clusters were considered successful as professional learning groups, but for the most part they fell short of developing a critical learning culture that affected change in teaching (Ward \& Henderson, 2011). 'Learning and Change Networks' (LCN) was a strategy introduced by the 
Ministry of Education in 2012 with the goal of improving student achievement through schools clustering and collaboration (Annan \& Carpenter, 2014). LCN key features were placing the learner at the centre of the network; schools, community and whanau voluntary collaboration; and facilitated support to cross pollinate ideas and build system capacity. LCN was considered a model of successful schools' collaboration that would inform the development of the "Investing in Educational Success" (IES) initiative (Patterson, 2014).

IES was announced by the government early in 2014 as a substantial investment, 359 million dollars, to raise student achievement through schools' collaboration. A key feature would be the creation of geographically based "Communities of Schools" that would work collaboratively towards shared achievement goals. Communities would be self-identifying, voluntary, and of mixed types, primary and secondary. There would be new roles and career pathways created that would be negotiated with the teacher unions and included in teacher collective agreements. Also included was a principals' recruitment allowance for high need schools, teacher release time for inquiry, and a "Teacher Led Innovation Fund" providing contestable funds for teacher led inquiry projects (Investing in Educational Success Working Group, 2014). There was push back from the New Zealand Education Institute (NZEI), the primary teachers' union, who voted an overwhelming $93 \%$ no confidence in the IES strategy. They felt that this substantial investment in education was mostly an investment in teachers' salaries and would be better spent in areas of higher need such as special needs education, that top down collaboration would not be genuine, and that the sector had not been adequately consulted in the development of IES (Barback, 2014; Wylie, 2016). A joint initiative working party was established to shape IES, where the NZEI sought to widen the curriculum scope beyond national standards, include early childhood education, include support staff, and identify successful features of collaboration to inform the new strategy (New Zealand Education Institute and Ministry of Education, 2015; Wylie, 2016).

Through further consultation with the Joint Initiative Working Party the IES strategy became Communities of Learning/Kahui Ako. By 2016, two thirds of New Zealand schools were engaged in a "Community of Learning" (CoL), either in the initial setup process or within an established CoL (Wylie, 2016; 2017b). A national survey of schools in 2016 found that many involved in CoLs realised that this strategy was a big system change for New Zealand education; and although there was some optimism about the potential of CoLs to enable collaboration, improve student achievement, ease school transitions and access resources, there were also many tensions. Many primary schools felt that achievement goals were too narrowly focused on national standards, and the Ministry of Education was playing too much of a role in setting them. There was tension around the appointment of key across school roles, and a feeling that CoL work came at an expense to their own school in terms of higher workloads and sharing teachers. Some principals felt that they had a lack of choice in entering a CoL, being pressured to join to be able to access resources such as "Professional Learning and Development" (PLD) (Wylie, 2016). CoLs were described as being in the 'emergent stage,' requiring more time and support to bed down into the education system.

Other educational changes were in process, such as the recent Education (Update) Amendment Act and a proposed funding review for schools (Wylie, 2017b). The funding review was aimed at scrapping the decile rating system, whereby schools are funded according to the socio-economic demographic of their community, and moving to a system that is based on students' progress against the curricula, targeted funding for individual challenges such as special needs or disadvantaged backgrounds, and supplementary funding for small and isolated schools through network provision (Parata, 2016). The Education (Update) Amendment Act Update provided a raft of changes, including supporting the development of CoLs and the initiation of a regulatory framework for online learning, enabling the establishment of CoOLs (Kaye, 2017; Ministry of Education, 2017b; Wylie, 2017b). At the time of writing, the Education (Update) Amendment Act Update, in particular CoOLs, are being repealed by the current government and a new, wider review entitled Korero Matauranga/Let's Talk about Education is taking place.

\section{DIGITAL TECHNOLOGIES AND TWENTY-FIRST CENTURY LEARNING}

Alongside the major schooling changes of the last three decades, there have been several government initiatives and policies focused on digital technologies and twenty-first century learning that have been instrumental in the growth of virtual learning and school networks in New Zealand (Powell \& Barbour, 2011; Whalley, 2016). These key government educational policies were "Interactive Education an Information 
Communication and Technology Strategy for Schools" (Ministry of Education, 1998), "Digital Horizons" (Ministry of Education, 2002), and "Enabling 21st Century Learners" (Ministry of Education, 2006). These policies gave rise to projects such as Information Communication Technology Professional Development clusters, which enabled new networks such as the early VLN secondary clusters to grow (Arif, 2016; Barbour \& Wenmoth, 2013); and helped to foster an environment that was focussed on innovation and ICT, together with resources and professional support for teachers and schools who were extending into learning online (Langley, 2003; Powell \& Barbour, 2011).

The terms twenty-first century learning and future focused learning are used interchangeably and often linked with, though not exclusively related to, the use of digital technologies (Bolstad, Gilbert, McDowall, Bull, Boyd, \& Hipkins, 2012). They reflected:

an emerging cluster of ideas, beliefs, knowledge, theories and practices which have deep roots in contemporary theories about knowledge and learning in the context of the massive economic, social, technological, cultural, and environmental developments. (Bolstad, 2011, p. 78)

Bolstad et al. (2012), identified six principles for a future focused education system:

1. personalised learning - where the system is built around the needs of the learner;

2. new ways of thinking about equity, diversity and inclusivity;

3. a curriculum that uses knowledge to develop learning capacity;

4. a culture of continuous learning for educators and leaders;

5. rethinking the roles of learners and teachers; and

6. new ways of engaging schools with the wider community.

Sub-themes related to the roles of new technologies and collaborative practice are considered to be important to the development of future focused learning in schools, along with three key ideas of "'diversity,' 'connectedness' and 'coherence"' (p. 10). These principles, themes and key ideas provide a framework for policy makers, education leaders and teachers to develop a shared understanding on the future of schooling in New Zealand (Bolstad, 2011; Bolstad et al., 2012).

There has been no recent policy around twenty-first century learning or digital technologies in education as there had been in the previous decade. However, in 2012 the government commissioned an Education and Science Select Committee inquiry into twenty-first century learning environments and digital literacy to:

investigate and to make recommendations on the best structures, tools, and communities, in both rural and urban New Zealand, for enabling students and educators to attain the knowledge and skills, such as digital literacy, that the 21st century demands of us all. (Kaye, 2012, p. 9)

A reference group was formed and made recommendations on how the government could invest in people, learning environments and resources, collaborative networks, and infrastructure to build capability in the education sector (21st Century Learning Reference Group, 2014). Policy focus on digital technologies and future focused learning, has been important in supporting virtual learning in New Zealand schools.

Government policies and initiatives have provided direction and support, in the most part, to enable schools to work in more future focused collaborative ways. However, legacy systems such as Tomorrow's Schools can provide a barrier to schools working collaboratively, and new systems such as Kahui Ako are yet to be successfully implemented and embedded. With current reviews in progress the landscape looks set to change once again.

\section{SUMMARY}

This review has explored the relevant literature related to rural education, collaborative practice, andvirtual learning, particularly as it intersects to impact New Zealand schools. Small rural schools make up a large percentage of schools in the country, with $39 \%$ being sole charge, one to three teacher schools; and many of these receiving additional isolation funding. It is these small rural schools that have been identified by Stevens (1996) as leading the change in collaborative school networks and virtual learning. This reality continues to be the case with a large number of schools collaborating online through the VLN Primary schools' initiative. 
Small rural schools are literally the heart of their communities as they have close reciprocal relationships where they rely on the community for support and in turn the school is the hub of the community. As a result, children in small rural schools experience an education that has strong place based or local curriculum, high expectations for behaviour and achievement, and strong social connectedness. For these children transition to high school is an important time as it often means leaving their communities. Principals of small rural schools experience a range of challenges in their positions, some of which are exacerbated by their remote locations. Rural principals are challenged by work load issues, access to resources, professional isolation, multi-level teaching, managing relationships and the expectations of their communities. Innovative approaches such as partnering with community organisations and government, the use of digital technologies and collaborating across schools can assist in reducing the impact of these challenges.

Collaborative practice across schools can be a driver to increase professional capacity, lead change across networks of schools, and respond to diversity and provide equitable outcomes for students. Collaboration is a leadership practice whereby teachers develop collective efficacy believing that together they can achieve better outcomes for all their students, regardless of which school they attend. Grassroots or self-organising collaborative initiatives are often more effective than mandated collaboration as teachers and school leaders have greater commitment when setting their own collective goals based on mutual need and benefit. However, government mandated collaboration provides much needed resources, access to experts and formal structures that support sustainable collaborative school networks.

Virtual learning emerged in the 1990s in small rural schools and wharekura. With access to improved bandwidth, virtual learning has been growing in popularity and reach across New Zealand schools; most significantly in the primary school sector with $400 \%$ growth in recent years. Virtual learning provides a wide range of benefits for students and teachers in participating schools as well as being a driver for change in learner centred pedagogies, school organisation and resourcing. Some of the benefits described are access to a wider curriculum, professional support for teachers, flexibility and choice, personalised learning opportunities, social inclusiveness, development of digital literacy and intercultural awareness. Some of the challenges highlighted are the need for greater support for virtual learners in schools, a disconnect between online learning and classroom learning, the digital divide and access to reliable technology for all students. Support for virtual learners is critical and this literature review outlined guidelines for schools to provided effective learner support.

\section{IMPLICATIONS FOR PRACTICE AND FUTURE RESEARCH}

This literature review was designed to inform whanau, communities and schools to gain a better understanding of their children's virtual learning experiences and raise awareness of the potential benefits and challenges involved. Schools that are not yet involved in online collaboration may be interested to see the possibilities and to learn from experiences of those who have pioneered the space. Policy makers will find this review useful to be informed on past and current practice in collaborative online learning across schools and the potential benefits of virtual learning which can be realised for students, teachers and school communities within the New Zealand educational setting.

It is timely to discuss the importance of collaboration and virtual learning within the wider educational setting as the New Zealand government engages in a complete system wide review of education. The focus of this review aligns with Ministry of Education priorities in relation to collaborative practice and system changes within Communities of Learning or Kahui Ako, the Tomorrow's Schools Review and is particularly relevant to the legislation regarding CoOLs, which is currently being repealed through parliament. This current education review and policy direction underway will be important to determine how collaboration and virtual learning will develop into the future. As these legislative procedures near completion, it will be important for practitioners to continue to advocate for policies, regulations, and programs that will allow these innovative virtual learning programs to continue to engage in collaborative practices for rural schools.

Collaboration and virtual learning, pioneered and led by small rural schools, has been ongoing practice in New Zealand for many years; and with improvements in bandwidth speed and access to technology continues to spread to a greater number of schools and learners. Given the realities of the existing virtual learning system in New Zealand, there are many avenues for future research. For example, given the existing 
legislative procedures, future study could be conducted on the fundamental resourcing requirements of collaborative virtual learning initiatives and the legislative or policy environment that will support them to be an integral part of the New Zealand education system. This would ensure that the benefits of collaborative virtual learning that have been realised by many learners in small rural schools can be maintained and scaled across the wider school setting into the future. However, future research could also be conducted into how the lack of a specific focus on and recognition of virtual learning in the country has allowed the existing virtual learning programs to evolve in an organic fashion. Beyond the focus on the impact of policy, future study could also be focused on whether the lack of a formalized structure has influence the collaborative practices that have developed in the various virtual learning programs, and the nature of that influence. Finally, future research could examine the impact on rural schools that these informal collaborative practices that have been developed by the virtual learning programs have had.

\section{BIODATA and CONTACT ADDRESSES of AUTHORS}

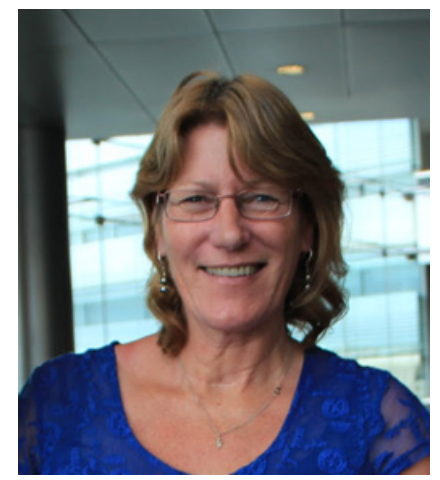

Rachel WHALLEY, leads the VLN Primary School, a collaboration of New Zealand schools that enable equity and access to education through online learning. Rachel gained her Master of Education in Educational Technology and Online Learning from the University of Waikato in 2018. She has published 3 peer reviewed journal articles, 1 book chapter, and presented at many conferences. Her interests are blended and online learning, online learning communities, pedagogy and curriculum development for online teaching and learning. Rachel has been active in online learning in New Zealand schools for many years as a teacher, professional learning leader, researcher and political advocate.

Rachel WHALLEY

VLN Primary School

Address: 10 Clem Elliott Drive, Matata, 3194, New Zealand

Phone: +64 276566140

E-mail: rache65@gmail.com

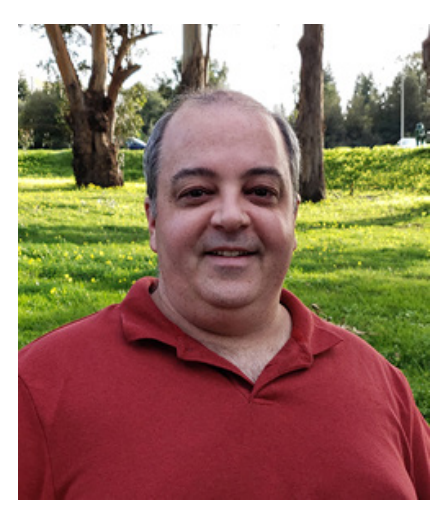

Michael K. BARBOUR, is Associate Professor of Instructional Design for the College of Education and Health Sciences at Touro University California. He has been involved with K-12 distance, online, and blended learning for more than two decades as a researcher, evaluator, teacher, course designer and administrator. Michael's research has focused on the effective design, delivery, and support of K-12 distance, online, and blended learning, particularly for students located in rural jurisdictions. This focus includes how regulation, governance and policy can impact effective distance, online, and blended learning environments. This has resulted in invitations to testify before House and Senate committees in several states, as well as consulting for Ministries of Education across Canada and in New Zealand.

Michael K. BARBOUR

College of Education and Health Sciences

Address: 1310 Club Drive, Vallejo, CA 94592, USA

Phone: +017076385952

E-mail: mkbarbour@gmail.com 


\section{REFERENCES}

21st Century Learning Reference Group. (2014). Future-focused learning in connected communities. Wellington, New Zealand: Ministry of Education. Retrieved from http://www.education.govt.nz/ assets/Documents/Ministry/Initiatives/FutureFocusedLearning30May2014.pdf

Ainscow, M. (2016). Collaboration as a strategy for promoting equity in education: possibilities and barriers. Journal of Professional Capital and Community, 1(2), 159-172. https://doi.org/10.1108/JPCC-122015-0013

Ali, A. (2017). The development of the learning exchange schools in New Zealand: An actor network theory and complexity theory analysis. An unpublished Ph.D. Thesis, Victoria University, Wellington, New Zealand. Retrieved from http://researcharchive.vuw.ac.nz/handle/10063/6457

Anderson, T., \& Dron, J. (2011). Three generations of distance education pedagogy. The International Review of Research in Open and Distributed Learning, 12(3), 80-97. https://doi.org/10.19173/ irrodl.v12i3.890

Annan, J., \& Carpenter, R. (2014). Learning and change networks: Connecting students with learning. Wellington, New Zealand: Aotearoa New Zealand Education Gazette. Retrieved from https:// gazette.education.govt.nz/articles/1H9csP-learning-and-change-networks-connecting-studentswith-learning/

Baills, L., \& Rossi, T. (2001). The transition from isolated, rural contexts to boarding school - Can school physical education and sport play a part? Journal of Physical Education New Zealand, 34(1), 40-52.

Barbour, M. K. (2011a). Primary and secondary e-learning: Examining the process of achieving maturity. Christchurch, New Zealand: Distance Education Association of New Zealand. Retrieved from http://www.vln.school.nz/mod/file/download.php?file_guid=114023

Barbour, M. K. (2011b). Addressing learner needs: An example from the VLN Primary. Retrieved from http:// www.vln.school.nz/groupcms/view/8282/learner-needs

Barbour, M. K. (2014). A history of international K-12 online and blended instruction. In R. Ferdig \& K. Kennedy (Eds)., Handbook of Research on K-12 Online and Blended Learning (pp. 25-50). Pittsburgh, PA: Entertainment Technology Center Press, Carnegie Mellon University. Retrieved from http://press.etc.cmu.edu/content/handbook-research-k-12-online-and-blended-learning-0

Barbour, M. K. (2015). US and international K-12 online learning: How have they developed differently? In D. Rutledge \& D. Slykhuis (Eds.), Proceeding of the 2015 Society for Information Technology \& Teacher Education International Conference (pp. 1446-1453). Chesapeake, VA: Association for the Advancement of Computing in Education. Retrieved from https://www.learntechlib. org $/ \mathrm{p} / 150584 /$

Barbour, M. K., Davis, N., \& Wenmoth, D. (2013). Networked Schools in New Zealand: Examples from the Virtual Learning Network. In R. McBride \& M. Searson (Eds.), Proceeding of the 2013 Society for Information Technology \& Teacher Education International Conference (pp. 4102-4107). Chesapeake, VA: Association for the Advancement of Computing in Education.. Retrieved from http://www.learntechlib.org/p/48763/

Barbour, M. K., Miron, G., \& Huerta, L. (2017). Virtual schools in the U.S.: Case studies of policy, performance, and research evidence. Lansing, MI: Michigan Virtual Learning Research Institute. Retrieved from http://media.mivu.org/institute/pdf/VSCase-17.pdf

Barbour, M., \& Wenmoth, D. (2013). Virtual learning as an impetus for educational change: Charting a way forward for learning in New Zealand. Christchurch, New Zealand: Core Education. Retrieved from http://digitalcommons.sacredheart.edu/ced_fac/93

Barley, Z. A., \& Beesley, A. D. (2007). Rural school success: What can we learn? Journal of Research in Rural Education, 22(1), 1-16. Retrieved from http://jrre.psu.edu/articles/22-3.pdf

Bartholomaeus, P. (2013). Educating for sustainable rural futures. Australian and International Journal of Rural Education, 23(2), 101-113. 
Bates, T. (2005). Technology, e-learning and distance education (2nd ed). New York: Routledge.

Bolstad, R. (2011). Principles for a future-oriented education system. New Zealand Annual Review of Education, 2011-2012(21), 77-95.

Bolstad, R., Gilbert, J., McDowall, S., Bull, A., Boyd, S., \& Hipkins, R. (2012). Supporting future-oriented learning \& teaching a New Zealand perspective. Wellington, New Zealand: Ministry of Education. Retrieved from http://www.educationcounts.govt.nz/_data/assets/pdf_file/0003/109317/994_ Future-oriented-07062012.pdf

Bolstad, R., \& Lin, M. (2009). Students' experiences of learning in virtual classrooms. Wellington, New Zealand: New Zealand Council for Educational Research. Retrieved from http://www.nzcer.org.nz/system/ files/students-experiences-learning-virtual-classrooms.pdf

Borup, J., West, R. E., Graham, C. R., \& Davies, R. S. (2014). The adolescent community of engagement framework: A lens for research on K-12 online learning. Journal of Technology and Teacher Education, 22(1), 107-129.

Cavanaugh, C., Ferdig, R. E., \& Freidhoff, J. R. (2015). Research into K-12 online \& blended learning. In T. Clark \& M. Barbour (Eds.), Online, Blended and Distance Education in Schools: Building Successful Programs (pp. 52-59). Sterling, VA: Stylus Publishing, LLC.

Chapman, C., Chestnutt, H., Friel, N., Hall, S., \& Lowden. K., (2016). Professional capital and collaborative inquiry networks for educational equity and improvement? Journal of Professional Capital and Community, 1(3), 178-197. https://doi.org/10.1108/JPCC-03-2016-0007

Cloke, P. J. (2006). Conceptualizing rurality. In P. Cloke, T. Marsden \& P. Mooney (Eds.), Handbook of Rural Studies (pp. 18-29). Thousand Oaks, CA: SAGE.

Corbett, M. (2007). Travels in space and place: Identity and rural schooling. Canadian Journal of Education, 30(3), 771-792.

Cowie, B., \& Hipkins, R. (2009). Curriculum implementation exploratory studies: Final report. Wellington, New Zealand: Ministry of Education. Retrieved from http://www.educationcounts.govt.nz/_ data/assets/pdf_file/0008/57824/930_CIESweb.pdf

Crothers, C., Smith, P., Urale, P., \& Bell, A. (2016). The internet in New Zealand 2015. Auckland, New Zealand: Institute of Culture, Discourse \& Communication, Auckland University of Technology. Retrieved from https://icdc.aut.ac.nz/_data/assets/pdf_file/0020/73442/WIPNZ-Report-060515.pdf

Daly, A. J. (Ed.). (2010). Social network theory and educational change. Cambridge, MA: Harvard Education Press.

Donehower, K., Hogg, C. \& Schell, E. (2007). Rural literacies. Carbondale, IL: Southern Illinois University Press.

Donohoo, J. (2017). Collective efficacy: How educators' beliefs impact student learning. Thousand Oaks, CA: Corwin.

Duffy, G., \& Gallagher, T. (2017). Shared education in contested spaces: How collaborative networks improve communities and schools. Journal of Educational Change, 18(1), 107-134. https://doi. org/10.1007/s10833-016-9279-3

Duke, B., Harper, G., \& Johnston, M. (2013). Connectivism as a digital age learning theory. In L. Stefani, S. Tegginmath, \& B. Todhunter (Eds.), The International HETL Review (pp. 4-13). Kew Gardens, NY: The International Higher Education Teaching and Learning Association Retrieved from https://www.hetl.org/wp-content/uploads/2013/09/HETLReview2013SpecialIssueArticle1.pdf

Earl Rinehart, K. (2017). Judging what they do: Formal, informal, and self appraisal of New Zealand (rural) primary school principals. An unpublished Ph.D. Thesis, University of Waikato, Hamilton, New Zealand. Retrieved from https://researchcommons.waikato.ac.nz/handle/10289/11543

Education Review. (2016, April). A Matter of Principal. Education Review: Leadership \& Professional Development 2016. Retrieved from http://educationreview.co.nz/a-matter-of-principal/ 
East, L. (2016). Why COOLs are so uncool... What the Education (Update) Amendment Bill means for you? New Zealand Principal Nga Tumuaki O Aotearoa, 31(4), 31-32.

Feys, E., \& Devos, G. (2015). What comes out of incentivized collaboration: A qualitative analysis of eight Flemish school networks. Educational Management Administration \& Leadership, 43(5), 738-754. https://doi.org/10.1177/1741143214535738

Fullan, M. (2005). Professional learning communities writ large. In R. DuFour, R. E. Eaker, \& R. B. DuFour (Eds.), On common ground: the power of professional learning communities (pp. 209-224). Bloomington, IN: National Educational Service.

Fullan, M. (2015, June 9). Learning is the work. Motion Leadership. Retrieved from https://michaelfullan. $\mathrm{ca} /$ topic-video-learning-is-the-work/

Garrison, D., Anderson, T., \& Archer, W. (2010). The first decade of the community of inquiry framework: A retrospective. The Internet and Higher Education, 13, 5-9. https://doi.org/10.1016/j. iheduc.2009.10.003

Gibson, J. (2009). Virtual Learning Network (VLN) Primary/Intermediate cluster development plan - Milestone 1. Masterton, New Zealand: Authentic Encounters Online.

Government of New Zealand. (2018). Korero Matauranga let's talk about Education. Wellington, New Zealand: Author. Retrieved from https://conversation.education.govt.nz/

Green, B. (2015). Australian education and rural-regional sustainability. Australian and International Journal of Rural Education, 25(3), 36-49.

Guri-Rosenblit, S. (2005). 'Distance education' and 'e-learning': Not the same thing. Higher Education, 49(4), 467-493. https://doi.org/10.1007/s10734-004-0040-0

Halfacree, K. (2006). Rural space: constructing a three-fold architecture. In P. Cloke, T. Marsden \& P. Mooney (Eds.), Handbook of Rural Studies (pp. 44-63). Thousand Oaks, CA: SAGE.

Harasim, L. (2014). Learning theory and online technologies. London: Taylor and Francis.

Hargreaves, A., \& O'Connor. M.T. (2017). Cultures of professional collaboration: their origins and opponents. Journal of Professional Capital and Community, 2(2), 74-85. https://doi.org/10.1108/ JPCC-02-2017-0004

Hayward, J. (2008). Sabbatical report from Jeff Hayward, Principal, Waimata Valley School, Gisborne. Gisborne, New Zealand: Waimata Valley School. Retrieved from http://www.educationalleaders.govt.nz/ Leadership-development/Principals-sabbatical-reports/Report-archives-for-2007-2015/Primaryaward-recipients-2008

Investing in Educational Success Working Group. (2014). Investing in educational success: Working group report. Wellington, New Zealand: Ministry of Education. Retrieved from http://www.education. govt.nz/assets/Documents/Ministry/Investing-in-Educational-Success/Investing-in-EducationalSuccess-Working-Group-Report-3-June-2014.pdf

Johnson, K. (2016). Investigating how to better prepare our students for the transition to boarding school. Wellington, New Zealand: Ministry of Education. Retrieved from http://www.educationalleaders. govt.nz/Leadership-development/Principals-sabbatical-reports/Primary-award-recipients-2016

Kaye, N. (2012). Inquiry into 21st century learning environments and digital literacy. Wellington, New Zealand: Education and Science Committee, Parliament. Retrieved from https://www.parliament. nz/resource/en-NZ/50DBSCH_SCR5695_1/b6ed634f8930f5797df8b91ca9f4a519e0e6608d

Kaye, N. (2017). Biggesteducation reform in decadespasses final reading. Wellington, New Zealand: Government of New Zealand. Retrieved from https://www.beehive.govt.nz/release/biggest-education-reformdecades-passes-final-reading

Kearns, R. A., Lewis, N., McCreanor, T., \& Witten, K. (2009). 'The status quo is not an option': Community impacts of school closure in South Taranaki, New Zealand. Journal of Rural Studies, 25(1), 131140. https://doi.org/10.1016/j.jrurstud.2008.08.002 
Kop, R., \& Hill, A. (2008). Connectivism: Learning theory of the future or vestige of the past? The International Review of Research in Open and Distributed Learning, 9(3). Retrieved from http:// www.irrodl.org/index.php/irrodl/article/view/523

Lai, K.W., Pratt, K., \& Grant, A. (2003). State of the art and trends in distance, flexible, and open learning: A review of the literature. Dunedin, New Zealand: University of Otago. Retrieved from http://www. otago.ac.nz/courses/distance_study/pdf/distance_lit_review.pdf

Langley, M. (2003). Case study of the Cantatech and TOSItech distance learning projects. An unpublished Master's Thesis, University of Canterbury, Christchurch, New Zealand. Retrieved from https:// ir.canterbury.ac.nz/handle/10092/2869

Langley, J. (Ed.). (2009). Tomorrow's schools 20 years on. Auckland, New Zealand: Cognition Institute. Retrieved from http://www.cognitioneducationtrust.org/wp-content/uploads/2013/09/report_ cognition_institute_john_langley_ed.pdf

McLean, F. M., Dixon, R. M., \& Verenikina, I. (2014). Bringing it to the teachers: Building a professional network among teachers in isolated schools. Australian and International Journal of Rural Education, 24(2), 15-22.

Mcleod, H. (2015, May). Families respond to Stewart Island school's plea. The Southland Times. Retrieved from https://www.stuff.co.nz/southland-times/news/68590864/Families-respond-to-StewartIsland-schools-plea

Ministry of Education. (1998). Interactive education: An information and communication technologies strategy for schools. Wellington, New Zealand: Author.

Ministry of Education. (2002). Digital horizons: Learning through ICT. Wellington, New Zealand: Author.

Ministry of Education. (2006). Enabling the 21st century learner: An e-learning action plan for schools, 20062010. Wellington, New Zealand: Author.

Ministry of Education. (2011a). Learning communities online: A support handbook for cluster schools. Wellington, New Zealand: Author. Retrieved from http://www.vln.school.nz/groups/profile/2644/ lco-handbook

Ministry of Education. (2011b). Creating educationally powerful connections. The New Zealand Curriculum Update (14). Retrieved from http://nzcurriculum.tki.org.nz/content/download/9502/127180/ file/NZC-update-14.pdf

Ministry of Education. (2013). School ICT infrastructure survey. Wellington, New Zealand: Author. Retrieved from http://www.educationcounts.govt.nz/publications/schooling/school-ict-infrastructuresurvey

Ministry of Education. (2016). Funding for isolation across schooling and early learning. Wellington, New Zealand: Author. Retrieved from https://education.govt.nz/assets/Uploads/Funding-for-Isolationacross-Schooling-and-ECE.docx

Ministry of Education. (2017a). New Zealand schools. Wellington, New Zealand: Author. Retrieved from http://www.educationcounts.govt.nz/data-services/directories/list-of-nz-schools

Ministry of Education. (2017b). Your guide to the new Education Update Act 2017. Wellington, New Zealand: Author. Retrieved from https://education.govt.nz/assets/Documents/Ministry/Legislation/EdAct-Update-Factsheets/Update-to-the-Ed-Act-Diagram-AW.pdf

Ministry of Education. (2018). Our schooling futures: Stronger together Whiria Nga Kura Tüatinitini. Report by the Tomorrow's Schools Independent Taskforce. Wellington, New Zealand: Ministry of Education. Retrieved from https://conversation.education.govt.nz/assets/TSR/Tomorrows-Schools-ReviewReport-13Dec2018.PDF

Moore, M. G., \& Kearsley, G. (2012). Distance education: a systems view of online learning (3rd ed). Belmont, CA: Wadsworth Cengage Learning. 
New Zealand Education Institute, \& Ministry of Education. (2015). Joint initiative governance group report. Wellington, New Zealand: Ministry of Education. Retrieved from https://www.nzei.org.nz// documents/JI/Joint-Initiative-Working-Party-Report.pdf

O'Leary, H. A. A. (2015). Leading learning for Maori students: The challenges of leadership for teaching principals in small rural primary schools. Auckland, New Zealand: Unitec Institute of Technology. Retrieved from http://unitec.researchbank.ac.nz/handle/10652/3260

Owen, H. (2011). Personalised, contextualised professional learning development: Putting it into practice. Journal of Open Flexible and Distance Learning, 15(1), 61-74.

Owen, H. (2013). Interview with Eddie Reisch. Journal of Open Flexible and Distance Learning, 17(1), 4655.

Palloff, R. M., \& Pratt, K. (2008). Building online learning communities effective strategies for the virtual classroom. New York: John Wiley \& Sons. Retrieved from http://nbn-resolving.de/ urn:nbn:de:101:1-201412148745

Palys, T. (2008). Purposive sampling. In L.M. Given (Ed.) The Sage Encyclopedia of Qualitative Research Methods (Vol. 2, pp. 697-698). Los Angeles, CA: SAGE.

Parata, H. (2016). Review of educational funding: update and next steps (Cabinet paper). Wellington, New Zealand: New Zealand Parliament | Paremata Aotearoa. Retrieved from http://www.education. govt.nz/assets/Uploads/R-SOC-16-SUB-0143-Paper-Review-of-Education-Funding-Systems.pdf

Parkes, M., Gregory, S., Fletcher, P., Adlington, R., \& Gromik, N. (2015). Bringing people together while learning apart: Creating online learning environments to support the needs of rural and remote students. Australian and International Journal of Rural Education, 25(1), 65-77.

Patterson, R. (2014). No school is an island: Fostering collaboration in a competitive system. Wellington, New Zealand: The New Zealand Initiative. Retrieved from https://nzinitiative.org.nz/reports-andmedia/reports/no-school-is-an-island/

Powell, A., \& Barbour. M. K., (2011). Tracing international differences in online learning development: An examination of government policies in New Zealand. Journal of Open, Flexible and Distance Learning, 15(1), 75-89.

Preston, J. P., Jakubiec, B. A. E., \& Kooymans, R. (2013). Common challenges faced by rural principals: A review of the literature. The Rural Educator, 35(1). Retrieved from http://epubs.library.msstate. edu/index.php/ruraleducator/article/view/119

Rincón-Gallardo, S., \& Fullan. M., (2016). Essential features of effective networks in education. Journal of Professional Capital and Community, 1(1), 5-22. https://doi.org/10.1108/JPCC-09-2015-0007

Roberts, R. (2009). Video conferencing in distance learning: A New Zealand schools' perspective. Journal of Distance Learning, 13(1), 91-107.

Roberts, R. (2010). Increasing access for learners - The Virtual Learning Network. In V. Ham \& D. Wenmoth (Eds.), e-Learnings: Implementing a national strategy for ICT in education, 1998-2010 (pp. 144-152). Christchurch, New Zealand: CORE Education Ltd.

Roberts, R. (2014, November). Look out they are coming! DEANZ Magazine. Retrieved from http://flanz. org.nz/flanzorg/wp-content/uploads/2016/06/Nov14.pdf

Ronfeldt, M., Farmer, S. O., McQueen, K., \& Grissom, J. A. (2015). Teacher collaboration in instructional teams and student achievement. American Educational Research Journal, 52(3), 475-514. https:// doi.org/10.3102/0002831215585562

Siemens, G. (2005). Connectivism: A learning theory for the digital age. International Journal of Instructional Technology \& Distance Learning, 2(1), 3-10.

Staker, H., \& Horn, M., B. (2012). Classifying K-12 blended learning. Redwood City, CA: Innosight Institute. Retrieved from https://www.blendedlearning.org/wp-content/uploads/2014/11/Classifying-K12-blended-learning.pdf 
Stansfield, J. (2015, May). Report to the New Zealand School Trustees Association [Remote schools and their communities: What can we learn from the small island study. Report from school isolation research]. Paper presented at Sole Charge \& Rural Teaching Principals Conference, Massey University, Havelock North, New Zealand. Retrieved from http://unitec.researchbank.ac.nz/handle/10652/3326

Starkey, L. (2012). Teaching and learning in the digital age. New York: Routledge.

Starkey, L., \& Stevens, K. J. (2007). Three stages in the digital integration of New Zealand schools. New Zealand Annual Review of Education, 16, 105-117.

Starr, K., \& White, S. (2008). The small rural school principalship: Key challenges and cross-school responses. Journal of Research in Rural Education, 23(5), 1-12.

Statistics New Zealand. (2004). New Zealand: An urban/rural profile. Wellington, New Zealand: Author. Retrieved from http://www.stats.govt.nz/browse_for_stats/Maps_and_geography/Geographicareas/urban-rural-profile.aspx

Stelmach, B. L. (2011). A synthesis of international rural education issues and responses. The Rural Educator, 32(2). Retrieved from http://epubs.library.msstate.edu/index.php/ruraleducator/article/view/161

Stevens, K. J. (1995). Some policy considerations in the changing relationship between area schools and New Zealand rural communities. Wellington, New Zealand: Victoria University of Wellington. Retrieved from https://www.msd.govt.nz/documents/about-msd-and-our-work/publications-resources/ journals-and-magazines/social-policy-journal/spj05/spj5-some-policy.doc

Stevens, K. J. (1996). The technological challenge to the notion of rurality in New Zealand education Repositioning the small school. New Zealand Annual Review of Education, 5, 93-102.

Stevens, K. J. (1998). Telelearning and contexts of awareness at Ngata Memorial College: te pouaka whakaako ki te Kareti o Ngata. Wellington, New Zealand: Te Puni Kokiri.

Stevens, K. J. (2010). An open learning matrix to sustain education in rural New Zealand. In J. Kidman \& K. Stevens, Looking Back from the Centre: A Snapshot of Contemporary New Zealand Education (pp. 161-172). Wellington, New Zealand: Victoria University Press.

Stevens, K. J., \& Moffatt, C. (2003). From distance education to elearning: the organization of open classes at local, regional and national levels. In J. Bradley (Ed.), The Open Classroom: Distance Learning In and Out of Schools. (pp. 171-180). London; Sterling, VA: Kogan Page.

Stevens, K. J., \& Stewart, D. (2005). Cybercells: Learning in actual and virtual groups. Melbourne, Australia: Thomson/Dunmore Press.

Stevens, K. M. (2011). The distribution of instructional leadership in eLearning clusters: an ecological perspective. An unpublished Master's Thesis, University of Canterbury, Christchurch, New Zealand. Retrieved from https://ir.canterbury.ac.nz/handle/10092/5446

Stockton, M. (2009). Meeting the demands of a new curriculum philosophy: A study of the challenges of curriculum implementation for small rural schools in New Zealand. An unpublished Master's thesis, Unitec Institute of Technology, Auckland, New Zealand. Retrieved from https://unitec.researchbank. ac.nz/handle/10652/1421

Taskforce on Regulations Affecting School Performance. (2014). Considering education regulation in New Zealand. Wellington, New Zealand: Ministry of Education. Retrieved from http:// www.minedu.govt.nz/theMinistry/EducationInitiatives/ /media/MinEdu/Files/TheMinistry/ EducationInitiatives/Taskforce/TaskforceReport.pdf

Taylor-Patel, C. (2014). Networking - Weaving the net; Gathering the pearls. Auckland, New Zealand: Auckland Primary Principals' Association. Retrieved from http://appa.org.nz/wp-content/uploads/2014/11/ Cherie-Taylor-Patel.pdf

Thomson, D. (2011). Conversations with teachers on the benefits and challenges of online learning for gifted students. Gifted Child Today, 34(3), 31-39. https://doi.org/10.1177/107621751103400309 
Tokas, S. (2016). Education and social capital. Learning Community: An International Journal of Educational and Social Development, 7(3), 257-265.

Tolosa, C., East, M., Barbour, M. K., \& Owen, H. (2017). Cool or not cool? Learning an Asian language online in the context of communities of online learning. The New Zealand Language Teacher, 43, $51-62$.

Vincent, J. (2015). Are our students from remote lisolated rural schools prepared for their transition to high school/boarding school? Whangamomona, New Zealand: Marco School. Retrieved from http:// www.educationalleaders.govt.nz/Leadership-development/Principals-sabbatical-reports/Reportarchives-for-2007-2015/Primary-award-recipients-2015

Virtual Learning Network Primary School. (2016). Submission on the Education (Update) Amendment Bill. Wellington, New Zealand: Government of New Zealand. Retrieved from https://www.parliament. $\mathrm{nz} / \mathrm{en} / \mathrm{pb} / \mathrm{sc} / \mathrm{submissions}$-and-advice/document/51SCES_EVI_00DBHOH_BILL69778_1_ A539002/virtual-learning-network-primary-school

Virtual Learning Network Primary School. (2017). VLN Primary school charter \& strategic plan 2018 - 2020: Connected passionate purposeful learners. Matata, New Zealand: Author. Retrieved from http:// vlnprimary.school.nz/hail_article/connected-passionate-purposeful-learners/

Waiti, P. (2005). Evaluation of Kaupapa ara whakawhiti matauranga (KAWM). Wellington, New Zealand: New Zealand Council for Educational Research. Retrieved from https://www.educationcounts. govt.nz/_data/assets/pdf_file/0011/6959/kawm.pdf

Ward, L., \& Henderson, A. (2011). An evaluation of network learning communities. Wellington, New Zealand: Ministry of Education. Retrieved from https://www.educationcounts.govt.nz/_data/ assets/pdf_file/0004/91417/968_NLCEvaluation.pdf

Wenger, E. (2008). Communities of practice: Learning, meaning, and identity. Cambridge, England: Cambridge University Press.

Wenmoth, D. (1996). Learning in the distributed classroom. SET Research Information for Teachers, 2(4). $1-4$.

Whalley, R. [Rachel]. (2017). CoOLs or Not CoOLs? A sustainable future for online learning in NZ primary schools. Matata, New Zealand: Virtual Learning Network Primary. Retrieved from https://hail.to/ vln-primary-school/publication/tzIg7Dy/article/NkExMWv

Whalley, R. [Rick]. (2016). Supporting student independence in virtual learning within New Zealand primary schools: Investigating the role of the school based support staff. An unpublished Master's Dissertation, University of Waikato, Hamilton, New Zealand. Retrieved from https://hail.to/vln-primaryschool/publication/uFS8PKk/article/UszM1DK

Williamson-Leadley, S., \& Pratt, K. (2017). New Zealand teacher educators' knowledge of and attitudes towards online and blended learning. In P. Resta \& S. Smith (Eds.), Proceedings of the 2017 Society for Information Technology \& Teacher Education International Conference (pp. 724-726). Chesapeake, VA: Association for the Advancement of Computing in Education. Retrieved from https://www.learntechlib.org/p/177875/

Windsor, B. (2010). Principals sabbatical report 2010. Aoraki Mount Cook, New Zealand: Aoraki Mount Cook School. Retrieved from http://www.educationalleaders.govt.nz/Leadership-development/ Principals-sabbatical-reports/Report-archives-for-2007-2015/Primary-award-recipients-2010

Wright, A. (2003). Preserving and affirming rural values through the curriculum. The Educational Forum, $68(1), 32-41$.

Wright, A. (2007). Reenergizing small communities: A vital role for rural schools. The Educational Forum, $71(4), 345-360$.

Wright, A. (2012). Creating and sustaining an "effective" rural school: The critical triad-leadership, curriculum, and community. An unpublished Ph.D. Thesis, University of Otago, Dunedin, New Zealand. Retrieved from https://ourarchive.otago.ac.nz/handle/10523/2526 
Wylie, C. (2012). Vital connections: Why we need more than self-managing schools. Wellington, New Zealand: New Zealand Council for Educational Research

Wylie, C. (2013). Tomorrow's schools after 20 years: Can a system of self-managing schools live up to its initial aims? The New Zealand Annual Review of Education (19). Retrieved from https://ojs. victoria.ac.nz/nzaroe/article/view/1555/1400

Wylie, C. (2016). Communities of learning |Kahui Ako: The emergent stage. Wellington, New Zealand: New Zealand Council for Educational Research. Retrieved from http://www.nzcer.org.nz/research/ publications/communities-learning-emergent-stage

Wylie, C. (2017a). Principals and their work: Findings from the NZCER national survey of primary and intermediate schools 2016. Wellington, New Zealand: New Zealand Council for Educational Research. Retrieved from http://www.nzcer.org.nz/system/files/National\%20Survey_Principals_ Nov17.pdf

Wylie, C. (2017b). Education in or for the 21st century? Policy Quarterly, 13(3), 8-11. 